Check for updates

Cite this: RSC Adv., 2017, 7, 24233

Received 17th March 2017

Accepted 26th April 2017

DOI: $10.1039 / c 7 r a 03176 a$

rsc.li/rsc-advances

\section{Thermophilic Enterococcus faecium QU 50 enabled open repeated batch fermentation for L-lactic acid production from mixed sugars without carbon catabolite repression $\uparrow$}

\author{
J. Tan, ${ }^{a}$ M. A. Abdel-Rahman, ${ }^{\text {ab }}$ M. Numaguchi, ${ }^{a}$ Y. Tashiro, ${ }^{\text {cd }}$ T. Zendo, ${ }^{a}$ K. Sakai ${ }^{\text {cd }}$ \\ and K. Sonomoto (iD *ae
}

\begin{abstract}
Enterococcus faecium QU 50, a novel thermophilic L-lactic acid (LA) producing strain, was used in this study to ferment sugar mixtures into LA. Under the optimal fermentation conditions $\left(50{ }^{\circ} \mathrm{C}, \mathrm{pH} 6.5\right)$, strain QU 50 could ferment both mixed glucose/xylose sugars with relaxed CCR and mixed cellobiose/xylose sugars simultaneously without CCR to produce homo L-LA. The activity of enzymes related to xylose metabolism was also investigated. In the cells grown in a medium containing cellobiose/xylose, the activity of xylose isomerase and xylulose kinase, was 3.22 and 1.91 times higher, respectively, as compared to that of cells grown in a glucose/xylose medium. Strain QU 50 produced $70.8 \mathrm{~g} \mathrm{~L}^{-1}$ of L-LA with a yield of $1.04 \mathrm{~g} \mathrm{~g}^{-1}$ and a productivity of $2.95 \mathrm{~g} \mathrm{~L}^{-1} \mathrm{~h}^{-1}$ from simulated energy cane hydrolysate in batch fermentation. Immobilisation of strain QU 50 improved the operational stability of open repeated fermentation (three cycles), resulting in $61.1-64.3 \mathrm{~g} \mathrm{~L}^{-1}$ of L-LA with a yield of 1.01-1.02 $\mathrm{g} \mathrm{g}^{-1}$ and a productivity of $3.22-3.82 \mathrm{~g} \mathrm{~L}^{-1} \mathrm{~h}^{-1}$. Thus, an efficient and cost-effective fermentation system was successfully established for L-LA production from sugar mixtures.
\end{abstract}

\section{Introduction}

For a long time, $\mathrm{LA}\left(\mathrm{CH}_{3}-\mathrm{CH}(\mathrm{OH})-\mathrm{COOH}\right)$ has been widely used in numerous industries such as pharmaceutical, cosmetic, chemical, and food industries. ${ }^{1-3}$ There are two LA isomers, $(++)-$ LA and D(-)-LA. Recently, biodegradable and biocompatible PLA, especially the PLLA synthesised from optically pure L-LA, has been used in numerous medical, pharmaceutical, and packaging products owing to its tensile strength, biocompatibility, and non-hazardous properties. ${ }^{4,5}$

${ }^{a}$ Laboratory of Microbial Technology, Division of Systems Bioengineering, Department of Bioscience and Biotechnology, Faculty of Agriculture, Graduate School, Kyushu University, 6-10-1 Hakozaki, Higashi-ku, Fukuoka 812-8581, Japan. E-mail: sonomoto@agr.kyushu-u.ac.jp; Fax: +81-92-642-3019; Tel: +81-92-642-3019

${ }^{b}$ Botany and Microbiology Department, Faculty of Science (Boys), Al-Azhar University, PN:11884, Nasr City, Cairo, Egypt

${ }^{c}$ Laboratory of Soil and Environmental Microbiology, Division of Systems Bioengineering, Department of Bioscience and Biotechnology, Faculty of Agriculture, Graduate School, Kyushu University, 6-10-1 Hakozaki, Higashi-ku, Fukuoka 8128581, Japan

${ }^{d}$ Laboratory of Microbial Environmental Protection, Tropical Microbiology Unit, Center for International Education and Research of Agriculture, Faculty of Agriculture, Kyushu University, 6-10-1 Hakozaki, Higashi-ku, Fukuoka 812-8581, Japan

${ }^{e}$ Laboratory of Functional Food Design, Department of Functional Metabolic Design, Bio-Architecture Center, Kyushu University, 6-10-1 Hakozaki, Higashi-ku, Fukuoka 812-8581, Japan

$\dagger$ Electronic supplementary information (ESI) available. See DOI: 10.1039/c7ra03176a
LA is produced by both chemical synthesis and microbial fermentation. However, the main disadvantage of the chemical synthesis route is that it results in the production of a racemic mixture of DL-LA. On the other hand, optically pure L- or D-LA can be produced by microbial fermentation and has several advantages, including utilisation of renewable resources, low energy consumption, and environment-friendly nature. ${ }^{6}$ Almost all LA produced today is by microbial fermentation processes. ${ }^{7}$

Recently, the industrial demand for LA, and especially that of PLA, has increased considerably, leading to an urgent requirement of low cost and non-food raw materials for the purpose. Lignocellulosic biomass has been regarded as a feasible substrate for LA production, because they are abundant, low cost, and are not used by humans as food sources. ${ }^{8}$ Lignocellulosic biomass mainly consists of cellulose (linear $\beta$-1,4-glucan), hemicellulose (heteropolysaccharides containing hexoses of galactose, glucose and mannose, and pentoses of xylose and arabinose), and lignin (an aromatic polymer). ${ }^{8}$ However, the utilisation of the mixed sugars derived from lignocellulosic biomass for LA production by LAB is challenging. This is because most LAB cannot utilise pentose sugars and those that can undergo hetero-fermentation and consequently produce by-products. ${ }^{9}$ Another major problem is the CCR, wherein the mixture of sugar derived from lignocellulose is consumed sequentially. These obstacles result in increased residual sugars and decreased LA concentration, yield, and productivity. ${ }^{10-12}$ 
Several fermentation modes (batch, fed-batch, continuous, and repeated batch) have been tried for LA production. ${ }^{2,9,13,14}$ However, batch and fed-batch fermentations suffer from substrate and/or product inhibition, which results in low cell density and low LA productivity. ${ }^{6,8,13}$ The main disadvantages of continuous fermentation are increased residual substrates and low LA concentration. ${ }^{\mathbf{1 3 , 1 5}}$ On the other hand, repeated batch fermentation, where a portion or all of the cells from a previous run are inoculated into the next run, has been reported to overcome the limitations of batch, fed-batch, and continuous fermentations. ${ }^{\mathbf{1 3 , 1 6 - 2 0}}$ Repeated batch fermentation has many advantages including a shorter fermentation time because of the high inoculum concentration and enhancement of LA productivity. It is also no need to prepare seed culture, and clean and sterilise the fermenter. ${ }^{\mathbf{1 3 , 2 1}}$

Cell density and stability are also considered as important factors affecting LA production process. ${ }^{22}$ Cell immobilisation, as a method of cell accumulation, can enhance cell density and stability efficiently to further improve LA productivity. ${ }^{6}$ Besides, non-sterile (open) condition has additional advantages in that it does not lead to the Maillard reaction and release of furfural, and streamlines the fermentation process. ${ }^{8}$ However, there is no report on LA production in repeated batch fermentation without CCR from mixed sugars by immobilised LAB under non-sterile conditions.

Recently, a novel thermophilic strain isolated and characterised in our laboratory, Enterococcus faecium QU 50, was reported to produce homo-L-LA from xylose with an optical purity of $\geq 99.2 \%$, an yield of $1.04 \mathrm{~g} \mathrm{~g}^{-1}$ under the optimal fermentation condition of $50{ }^{\circ} \mathrm{C}$ and $\mathrm{pH}$ of $6.5 .^{1}$ The fermentation of LA by strain QU 50 has not been investigated till date using lignocellulose-derived sugar mixture. Thus, the aim of this study was to establish an efficient fermentation system with lignocellulose-derived sugar mixtures (glucose, cellobiose, and xylose) by using strain QU 50 to produce homo-L-LA without byproducts and CCR under thermophilic conditions. In this study, batch and open repeated batch fermentations, with free and immobilised cells of strain QU 50, were also examined for establishing an efficient fermentation system.

\section{Experimental}

\section{Microorganisms and media}

The stock culture of E. faecium QU 50 was stored at $-80{ }^{\circ} \mathrm{C}$ in vials containing $15 \%$ (v/v) glycerol until use. Cell growth, inoculum preparation, and fermentation were conducted using a mMRS medium containing the following components (in $\mathrm{L}^{-1}$ ): $10 \mathrm{~g}$ peptone (Becton, Dickinson and Company; Sparks,

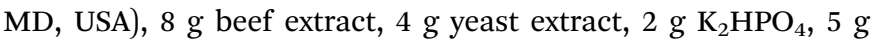
$\mathrm{CH}_{3} \mathrm{COONa} \cdot 3 \mathrm{H}_{2} \mathrm{O}, 2 \mathrm{~g}$ tri-ammonium citrate, $0.2 \mathrm{~g} \mathrm{MgSO}_{4}{ }^{-}$ $\cdot 7 \mathrm{H}_{2} \mathrm{O}, 0.05 \mathrm{~g} \mathrm{MnSO}_{4} \cdot 4 \mathrm{H}_{2} \mathrm{O}$ and $1 \mathrm{~mL}$ Tween 80 . The media was supplemented, as indicated in the different experiments, with different concentration of carbon sources such as glucose, xylose, and cellobiose (Carbosynth; Berkshire, UK). The pH of the medium was adjusted to 6.5 using $1 \mathrm{M} \mathrm{NaOH}$ or $1 \mathrm{M} \mathrm{HCl}$, and the media was sterilised at $115{ }^{\circ} \mathrm{C}$ for $18 \mathrm{~min}$. Sugar solutions and mMRS media were sterilised separately and then mixed for the utilisation of fermentations. On the other hand, unsterilised fermentation media were used in open batch and open repeated batch fermentations.

All the chemicals used in this study were purchased from Nacalai Tesque; Kyoto, Japan, unless mentioned otherwise.

\section{Fermentation processes}

Batch fermentations with sugar mixtures. For inoculum preparation, $1 \mathrm{~mL}$ of glycerol stock was inoculated into $9 \mathrm{~mL}$ mMRS medium containing $20 \mathrm{~g} \mathrm{~L}^{-1}$ xylose and refreshed for $24 \mathrm{~h}$ at $37^{\circ} \mathrm{C}$. Then, the pre-culture was performed by transferring $4 \mathrm{~mL}$ of the refreshed culture to a $100 \mathrm{~mL}$ flask containing a working volume of $40 \mathrm{~mL}$ and incubating it at $37{ }^{\circ} \mathrm{C}$ for $12 \mathrm{~h}$. All main cultures, batch and repeated batch fermentations with sugar mixtures performed by strain QU 50 in this study, were performed in a $1000 \mathrm{~mL}$ jar fermenter containing $400 \mathrm{~mL}$ of medium, and were incubated at $50{ }^{\circ} \mathrm{C}$ with an agitation rate of $200 \mathrm{rpm}$. Samples were taken at different time intervals and analysed for cell growth, sugar concentrations, and fermentation products.

For co-fermentation with glucose/xylose and cellobiose/ xylose, the pre-culture was performed with mMRS medium containing $20 \mathrm{~g} \mathrm{~L}^{-1}$ xylose. Sugar mixtures, containing G20X20 and C20X20, were used in mMRS medium for the main cultures. Batch fermentations were carried out by automatically maintaining the $\mathrm{pH}$ at 6.5 by addition of $10 \mathrm{M} \mathrm{NaOH}$.

For fermentation with simulated energy cane hydrolysate, preculture was performed with mMRS medium containing $2.5 \mathrm{~g} \mathrm{~L}^{-1}$ glucose, $20 \mathrm{~g} \mathrm{~L}^{-1}$ cellobiose, and $10 \mathrm{~g} \mathrm{~L}^{-1}$ xylose. ${ }^{9}$ In the main culture, G5C40X20 were supplemented in the mMRS medium. For investigation of the effects of different neutralising agents, the main culture was performed at $\mathrm{pH} 6.5$ maintained by addition of $10 \mathrm{M} \mathrm{NaOH}, \mathrm{KOH}$, or $\mathrm{NH}_{4} \mathrm{OH}$. For investigation of nonsterile fermentation with simulated energy cane hydrolysate, the main culture was performed with unsterilised medium with $\mathrm{pH}$ maintained at $6.5 \mathrm{using} 10 \mathrm{M} \mathrm{NH}_{4} \mathrm{OH}$.

Open repeated batch fermentations with simulated energy cane hydrolysate. Open repeated batch fermentations were performed for 3 runs in a $1000 \mathrm{~mL}$ jar fermenter containing $400 \mathrm{~mL}$ unsterilised medium supplemented with G5C40X20. Culture temperature was maintained at $50{ }^{\circ} \mathrm{C}$ and the $\mathrm{pH}$ was maintained at 6.5 by addition of $10 \mathrm{M} \mathrm{NH}_{4} \mathrm{OH}$. At the end of each batch fermentation performed with free cells, the broth was removed by centrifugation at $2900 \times g$ at $4{ }^{\circ} \mathrm{C}$. The harvested cells were suspended in a fresh medium to start the next run.

For the open repeated batch fermentation with immobilisation of cells, the pre-culture was centrifuged at $2900 \times g$ at $4{ }^{\circ} \mathrm{C}$ for $15 \mathrm{~min}$. The cells were then suspended in saline solution and mixed with an equal volume $(1: 1 \mathrm{v} / \mathrm{v})$ of $3 \%$ sodium alginate solution. Using a syringe, the mixture was then allowed to drop in a $3 \% \mathrm{CaCl}_{2}$ solution that was being continuously stirred. The formed beads entrapping bacterial cells were used for open repeated batch fermentation in media supplemented with $0.5 \% \mathrm{CaCO}_{3}$. At the end of each batch fermentation, the broth was removed, and all the beads were re-suspended in a fresh medium for the next run. Samples were taken at 
different time intervals and analysed for cell growth and composition of sugars and fermentation products.

\section{Enzyme assays}

For the preparation of crude enzyme extracts, cells were grown in mMRS medium with G20X20 or C20X20 for $2 \mathrm{~h}$ (where glucose or cellobiose still remained) and were later harvested by centrifugation at $1800 \times g$ for $10 \mathrm{~min}$ at $4{ }^{\circ} \mathrm{C}$. The harvested cells were washed with $0.85 \%(\mathrm{w} / \mathrm{v}) \mathrm{NaCl}$ and suspended in $2 \mathrm{~mL}$ of $50 \mathrm{mM}$ citrate phosphate buffer ( $\mathrm{pH} 7.0)$ as the cell suspension. For preparation of crude intracellular enzymes, $100 \mu \mathrm{L}$ of $100 \mathrm{~g}$ $\mathrm{L}^{-1}$ lysozyme (Wako; Osaka, Japan), $100 \mu \mathrm{L}$ of $200 \mathrm{mM} \mathrm{MgCl}_{2}, 8$ $\mu \mathrm{L}$ of 0.5 M DTT (Sigma-Aldrich; St Louis, MO, USA), $2 \mu \mathrm{L}$ of $2 \mathrm{~g}$ $\mathrm{mL}^{-1}$ DNAase (Sigma-Aldrich), and $20 \mu \mathrm{L}$ protease inhibitor cocktail (EDTA free $100 \times$, Nacalai Tesque) were added to the cell suspension, and then incubated at $37^{\circ} \mathrm{C}$ for $1 \mathrm{~h}$. Cell debris was removed by centrifugation at $13000 \times g$ for $15 \mathrm{~min}$ at $4{ }^{\circ} \mathrm{C}$. The supernatants were used as crude extracts for XI and XK assay, as described previously. ${ }^{8}$

\section{Analytical methods}

Cell growth was measured at an optical density of $562 \mathrm{~nm}\left(\mathrm{OD}_{562}\right)$ using a spectrophotometer (UV-1600; Shimadzu, Kyoto, Japan). One unit of $\mathrm{OD}_{562}$ corresponded to $0.246 \mathrm{~g}$ dry cell weight (DCW) per litre. Samples collected during fermentation were centrifuged at $7200 \times g$ at $4{ }^{\circ} \mathrm{C}$ for $10 \mathrm{~min}$ to remove cells, and supernatants were filtered through a membrane filter (Dismic-13HP, $0.45 \mu \mathrm{m}$; Advantec; Tokyo, Japan). Cellobiose, xylose, glucose, and fermentation products were analysed using high-performance liquid chromatography (HPLC; US HPLC-1210, Jasco; Tokyo, Japan) equipped with a SUGAR SH-1011 column (Shodex; Tokyo, Japan) at the following conditions: temperature: $50{ }^{\circ} \mathrm{C}, 3 \mathrm{mM}$ $\mathrm{HClO}_{4}$ as a mobile phase at a flow rate of $1.0 \mathrm{~mL} \mathrm{~min}^{-1}$ using an injection volume of $20 \mu \mathrm{L}$. DCW in beads was analysed after destroying the beads in $0.2 \mathrm{M}$ sodium citrate, which was expressed as the concentration in the working volume (broth). The optical purity of L-LA was detected by a BF-5 biosensor (Oji Scientific Instruments; Hyogo, Japan). Protein concentration in the crude cell extract was determined using a NanoDrop spectrophotometer, ND-1000 (Thermo Fisher Scientific Inc.; Waltham, MA, USA) based on the absorbance at $280 \mathrm{~nm}$.

\section{Results}

\section{Batch fermentation with sugar mixtures of glucose/xylose and} cellobiose/xylose

Three types of CCR are proposed in fermentations with sugar mixtures as follows (Fig. S1†): [1] significant CCR; a nonfavourable sugar (e.g. xylose) starts to be consumed after the exhaustions of the preferred sugar (e.g. glucose), which sometimes leads to incomplete consumptions of the non-favourable sugar (Fig. S1A $\dagger$ ), [2] relaxed CCR; a non-favourable sugar is consumed simultaneously with the lower consumption rate than that of preferred sugar (Fig. S1B $\dagger$ ), and [3] no CCR; nonfavourable sugar is consumed simultaneously with the similar consumption rate with that of preferred sugar, which often
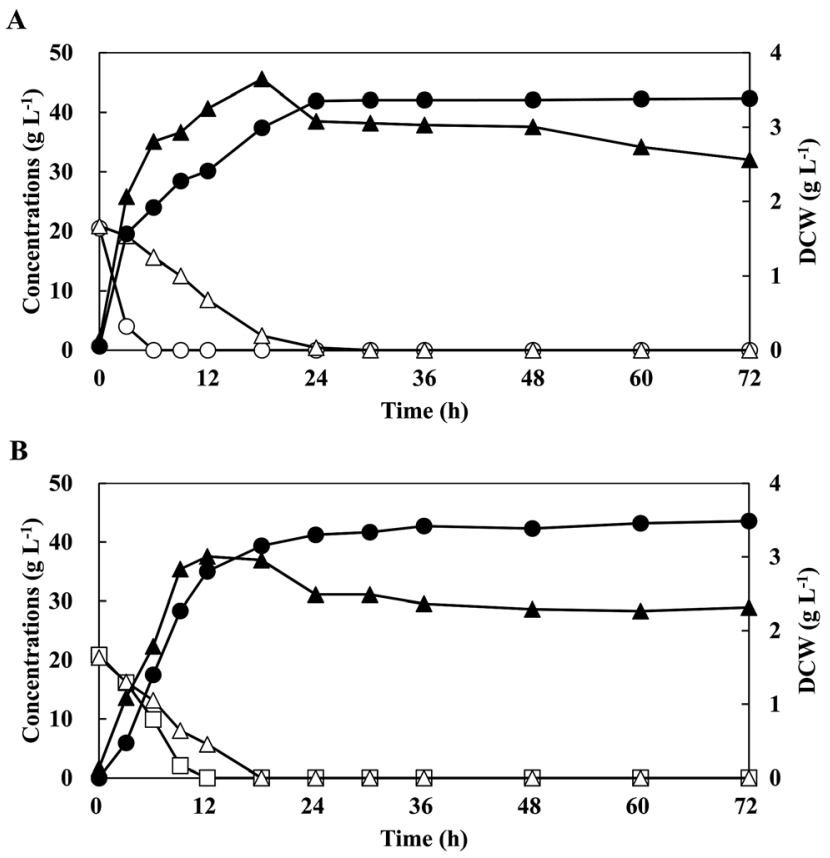

Fig. 1 Profile of lactic acid production from sugar mixtures G20X20 (A) and C20X20 (B). E. faecium QU 50 was cultured in a $1000 \mathrm{~mL}$ jar fermenter containing $400 \mathrm{~mL}$ mMRS medium at $50^{\circ} \mathrm{C}$, with agitation at 200 rpm and pH 6.5 (maintained using $10 \mathrm{M} \mathrm{NaOH}$ ). Symbols: open circles, glucose concentration; closed circles, lactate concentration; open triangles, xylose concentration; closed triangles, dry cell weight (DCW); and opened squares, cellobiose concentration. The data points represent the mean values obtained from three independent experiments.

results in complete consumptions (Fig. S1C $\dagger$ ). ${ }^{11}$ To investigate the utilisation of mixed sugars by strain QU 50, batch fermentations were conducted in a medium supplemented with G20X20 and C20X20 (Fig. 1 and Table 1). Strain QU 50 grew rapidly and reached a maximum DCW of $3.65 \mathrm{~g} \mathrm{~L}^{-1}$ and $3.00 \mathrm{~g}$ $\mathrm{L}^{-1}$ in G20X20 and C20X20, respectively. Sugar mixtures of G20X20 and C20X20 were consumed simultaneously during fermentations. Even in the presence of glucose in G20X20, $5.24 \mathrm{~g} \mathrm{~L}^{-1}$ xylose was consumed after $3 \mathrm{~h}$ and completely consumed within $30 \mathrm{~h}$. However, the consumption rate of $0.697 \mathrm{~g} \mathrm{~L}^{-1} \mathrm{~h}^{-1}$ was significantly lower than that of glucose (3.42 $\mathrm{g} \mathrm{L}^{-1} \mathrm{~h}^{-1}$ ). On the other hand, strain QU 50 completely consumed xylose in the batch fermentation with C20X20 within $18 \mathrm{~h}$ at a consumption rate $\left(1.14 \mathrm{~g} \mathrm{~L}^{-1} \mathrm{~h}^{-1}\right)$ similar to that of cellobiose $\left(1.74 \mathrm{~g} \mathrm{~L}^{-1} \mathrm{~h}^{-1}\right)$. These results indicated that strain QU 50 exhibited relaxed and no CCR in the fermentation with G20X20 and C20X20, respectively, and did not form any byproducts. Strain QU 50 effectively produced LA in the C20X20supplemented medium, leading to high concentration, yield, and productivity.

\section{Activities of enzymes involved in xylose metabolism in cultures grown with sugar mixtures}

In order to clarify the mechanism of the relaxed and no CCR for xylose consumption using glucose and cellobiose by strain QU 
Table 1 Kinetic parameters of lactic acid fermentation using sugar mixtures by $E$. faecium QU 50 in several fermentation modes

\begin{tabular}{|c|c|c|c|c|c|c|c|c|c|c|}
\hline $\begin{array}{l}\text { Mixed } \\
\text { sugars }^{a}\end{array}$ & $\begin{array}{l}\text { Fermentation } \\
\text { mode }\end{array}$ & $\begin{array}{l}\mathrm{pH} \\
\text { neutralizer }\end{array}$ & $\begin{array}{l}\text { Max. DCW } \\
\left(\mathrm{g} \mathrm{L}^{-1}\right)\end{array}$ & $\begin{array}{l}C_{\mathrm{Glc}^{b}} \\
\left(\mathrm{~g} \mathrm{~L}^{-1}\right)\end{array}$ & $\begin{array}{l}C_{\mathrm{Cel}}^{c} \\
\left(\mathrm{~g} \mathrm{~L}^{-1}\right)\end{array}$ & $\begin{array}{l}C_{\mathrm{Xyl}}^{d} \\
\left(\mathrm{~g} \mathrm{~L}^{-1}\right)\end{array}$ & $\begin{array}{l}\text { Max. LA } \\
\left(\mathrm{g} \mathrm{L}^{-1}\right)\end{array}$ & $\begin{array}{l}\text { Time } \\
\text { (h) }\end{array}$ & $\begin{array}{l}Y_{\mathrm{LA}}^{e} \\
\left(\mathrm{~g} \mathrm{~g}^{-1}\right)\end{array}$ & $\begin{array}{l}P_{\mathrm{LA}}^{f} \\
\left(\mathrm{~g} \mathrm{~L}^{-1} \mathrm{~h}^{-1}\right)\end{array}$ \\
\hline G20X20 & Batch & $\mathrm{NaOH}$ & $3.65(18 \mathrm{~h})$ & 20.5 & - & 20.9 & 41.7 & 30 & 1.01 & 1.39 \\
\hline G5C40X20 & Batch & $\mathrm{NaOH}$ & $3.67(12 \mathrm{~h})$ & 5.1 & 40.8 & 22.2 & 69.6 & 18 & 1.04 & 3.87 \\
\hline G5C40X20 & Batch & $\mathrm{KOH}$ & 3.65 (9 h) & 5.0 & 40.0 & 21.9 & 69.3 & 18 & 1.03 & 3.85 \\
\hline G5C40X20 & Batch & $\mathrm{NH}_{4} \mathrm{OH}$ & $3.87(12 \mathrm{~h})$ & 5.1 & 39.3 & 22.5 & 70.8 & 18 & 1.06 & 3.93 \\
\hline
\end{tabular}

${ }^{a} \mathrm{G} 20 \mathrm{X} 20$, glucose $20 \mathrm{~g} \mathrm{~L}^{-1}$ and xylose $20 \mathrm{~g} \mathrm{~L}^{-1}$; C20X20, cellobiose $20 \mathrm{~g} \mathrm{~L}^{-1}$ and xylose $20 \mathrm{~g} \mathrm{~L}^{-1}$; G5C40X20, glucose $5 \mathrm{~g} \mathrm{~L}^{-1}$, cellobiose $40 \mathrm{~g} \mathrm{~L} \mathrm{~L}^{-1}$ and xylose $20 \mathrm{~g} \mathrm{~L}^{-1} .{ }^{b}$ Glucose consumption. ${ }^{c}$ Cellobiose consumption. ${ }^{d}$ Xylose consumption. ${ }^{e}$ Yield of LA. ${ }^{f}$ Apparent productivity of LA.

Table 2 Xylose isomerase and xylulose kinase activities of $E$. faecium QU 50 grown in media containing glucose/xylose and cellobiose/ xylose after $2 \mathrm{~h}$ fermentation ${ }^{a}$

\begin{tabular}{lcl}
\hline Sugars $^{b}$ & $\begin{array}{l}\text { Xylose isomerase } \\
\text { (U per mg protein) }\end{array}$ & $\begin{array}{l}\text { Xylulose kinase } \\
\text { (U per mg protein) }\end{array}$ \\
\hline C20X20 & $0.140 \pm 0.001$ & $0.216 \pm 0.007$ \\
G20X20 & $0.0434 \pm 0.0014$ & $0.113 \pm 0.006$
\end{tabular}

${ }^{a}$ Averages with standard deviations are based on three independent fermentations. ${ }^{b} \mathrm{G} 20 \mathrm{X} 20$, glucose $20 \mathrm{~g} \mathrm{~L}^{-1}$ and xylose $20 \mathrm{~g} \mathrm{~L}^{-1}$; C20X20, cellobiose $20 \mathrm{~g} \mathrm{~L}^{-1}$ and xylose $20 \mathrm{~g} \mathrm{~L}^{-1}$.

50, XI and XK activities were measured in the strain grown in the presence of G20X20 and C20X20 after $2 \mathrm{~h}$ of fermentation (Table 2). In cells grown in the presence of G20X20, the activities of XI and XK were $0.0434 \pm 0.0014 \mathrm{U}$ per mg-protein and $0.113 \pm 0.006 \mathrm{U}$ per $\mathrm{mg}$-protein, respectively. In cells grown in the presence of C20X20, the activities of XI and XK were $0.140 \pm$ $0.001 \mathrm{U}$ per mg-protein and $0.216 \pm 0.007 \mathrm{U}$ per mg-protein, respectively, which were 3.22-fold and 1.91-fold higher than those obtained with cells grown in G20X20. The value of the specific xylose consumption rate obtained during $0-2 \mathrm{~h}$ of fermentation was also approximately 2 times higher in the C20X20-grown cells (1.03 $\mathrm{g} \mathrm{g}^{-1} \mathrm{~h}^{-1}$ ) when compared to the cells grown in G20X20 $\left(0.458 \mathrm{~g} \mathrm{~g}^{-1} \mathrm{~h}^{-1}\right)$. In addition, C20X20 exhibited about 3-fold higher specific LA production rate of $2.92 \mathrm{~g} \mathrm{~g}^{-1} \mathrm{~h}^{-1}$ as compared to $1.07 \mathrm{~g} \mathrm{~g}^{-1} \mathrm{~h}^{-1}$ obtained with G20X20. It was hypothesised that the high enzymatic activities of xylose metabolism could contribute to no CCR from sugar mixtures of cellobiose and xylose, resulting in enhanced LA production.

\section{Batch fermentation with simulated energy cane hydrolysate}

Energy cane has attracted considerable attention on the productions of valuable chemicals as the substrate. ${ }^{9,23}$ Simulated energy cane hydrolysate, as sugar mixtures containing cellobiose, glucose and xylose, was prepared with the respective commercial sugars according to each composition of enzymatic hydrolysate from energy cane bagasse. ${ }^{9,23}$ To investigate the feasibility of LA production with energy cane hydrolysate, ${ }^{9}$ batch fermentations were performed with mixed sugars of G5C40X20 under sterile conditions. Mixed sugars of $5.1 \mathrm{~g} \mathrm{~L}^{-1}$ glucose, $40.8 \mathrm{~g} \mathrm{~L}^{-1}$ cellobiose, and $22.2 \mathrm{~g} \mathrm{~L}^{-1}$ xylose were consumed simultaneously and completely without CCR (Table 1). The maximum DCW of $3.67 \mathrm{~g}$ $\mathrm{L}^{-1}$ was higher than that obtained from C20X20 $\left(3.00 \mathrm{~g} \mathrm{~L}^{-1}\right)$. The final LA concentration after $18 \mathrm{~h}$ culture was $69.6 \mathrm{~g} \mathrm{~L}^{-1}$ at an yield of $1.04 \mathrm{~g} \mathrm{~g}^{-1}$ and a productivity of $3.87 \mathrm{~g} \mathrm{~L}^{-1} \mathrm{~h}^{-1}$ and no byproducts were obtained. These results showed that the strain QU 50 was capable of producing homo-LA efficiently from energy cane hydrolysates without CCR.

To investigate the efficiency of the neutralising agents for LA production from simulated energy cane hydrolysate, batch fermentations were conducted using different neutralising agents such as $10 \mathrm{M} \mathrm{NaOH}, \mathrm{KOH}$, and $\mathrm{NH}_{4} \mathrm{OH}$ under sterile conditions (Table 1). Glucose, cellobiose, and xylose were simultaneously and completely consumed after $24 \mathrm{~h}$ without CCR when using $\mathrm{KOH}$

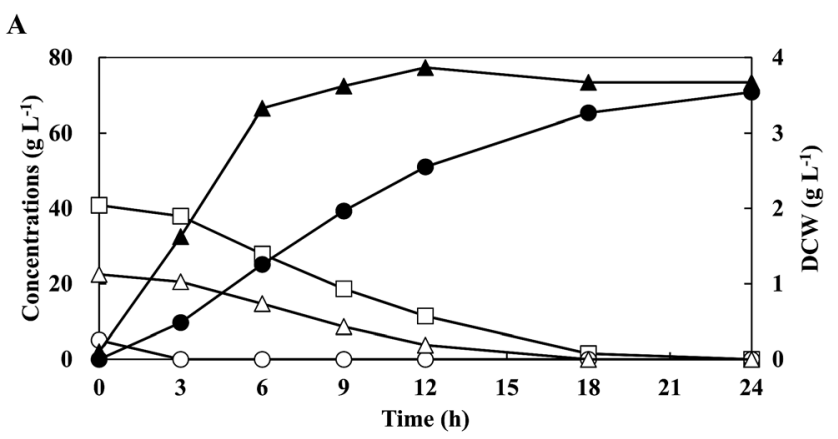

B

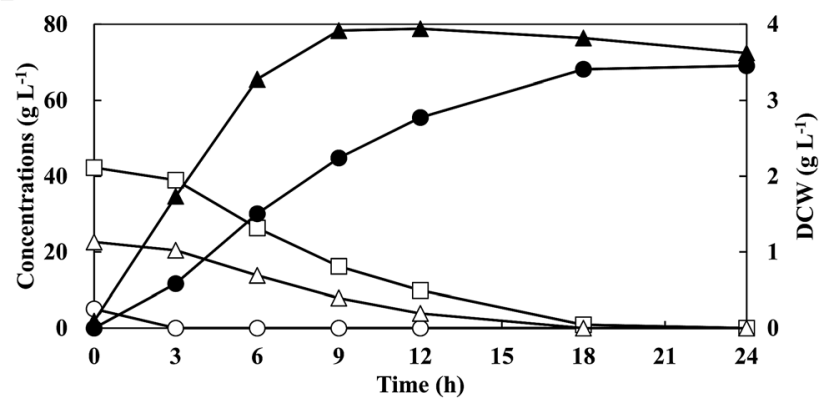

Fig. 2 Profile of lactic acid production by E. faecium QU 50 using simulated energy cane hydrolysate (G5C40X20) in batch fermentation using $\mathrm{NH}_{4} \mathrm{OH}$ as neutralising agent under sterile (A) and non-sterile (B) conditions. Symbols: opened circles, glucose concentration; closed circles, lactate concentration; open triangles, xylose concentration; closed triangles, dry cell weight (DCW); and opened squares, cellobiose concentration. The data points represent the mean values obtained from three independent experiments. 

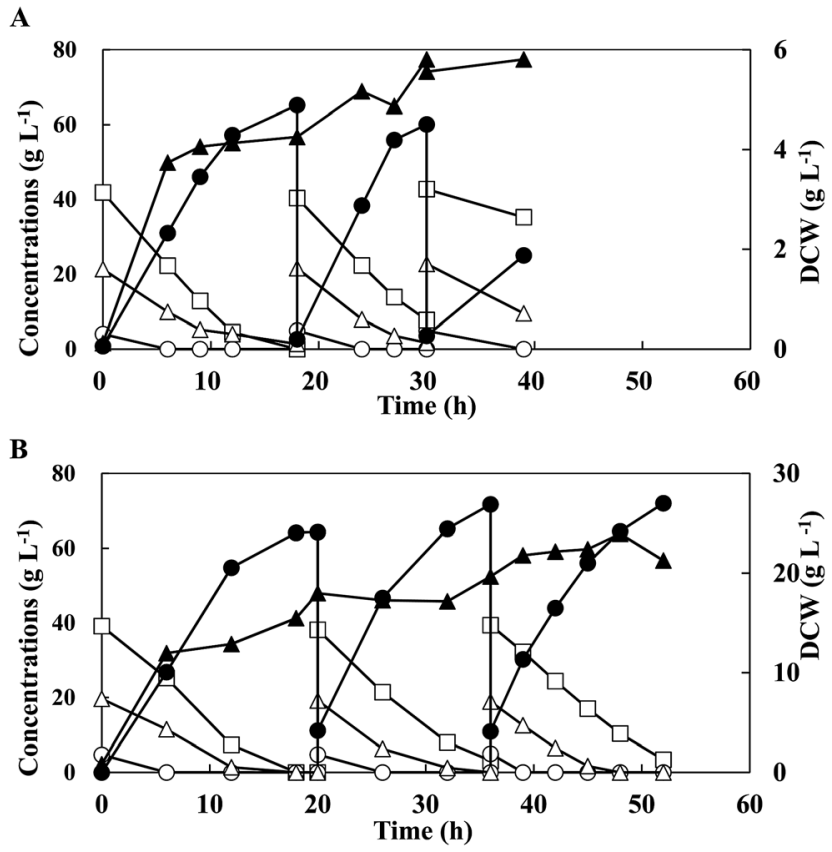

Fig. 3 Profile of lactic acid production by E. faecium QU 50 from simulated energy cane hydrolysate (G5C40X20) in open repeated batch fermentation by free (A) and immobilised (B) cells. Symbols: opened circles, glucose concentration; closed circles, lactate concentration; open triangles, xylose concentration; closed triangles, dry cell weight (DCW); opened squares, cellobiose concentration. The data points represent the mean values obtained from three independent experiments.

and $\mathrm{NH}_{4} \mathrm{OH}$ as neutralising agents, making it comparable with the $\mathrm{NaOH}$-controlled culture. The highest maximum DCW of $3.87 \mathrm{~g}$ $\mathrm{L}^{-1}$ with LA concentration of $70.8 \mathrm{~g} \mathrm{~L}^{-1}$, yield of $1.06 \mathrm{~g} \mathrm{~g}^{-1}$, and productivity of $3.93 \mathrm{~g} \mathrm{~L}^{-1} \mathrm{~h}^{-1}$ was achieved in $\mathrm{NH}_{4} \mathrm{OH}$-controlled cultures. Therefore, $\mathrm{NH}_{4} \mathrm{OH}$ was selected as the neutralising agent for all future LA fermentations.

To investigate the feasibility for LA production by strain QU 50 under open (non-sterile) conditions, batch fermentation with G5C40X20 was performed at a pH of 6.5 (controlled by $\mathrm{NH}_{4} \mathrm{OH}$ ) (Fig. 2B and Table 1). Glucose, cellobiose, and xylose were consumed simultaneously and completely $\left(5.1 \mathrm{~g} \mathrm{~L}^{-1}, 41.4 \mathrm{~g} \mathrm{~L}^{-1}\right.$, and $22.6 \mathrm{~g} \mathrm{~L}^{-1}$, respectively) without CCR after $18 \mathrm{~h}$. Furthermore, the LA concentration of $69.1 \mathrm{~g} \mathrm{~L}^{-1}$ with an yield of $1.00 \mathrm{~g} \mathrm{~g}^{-1}$ and a productivity of $3.84 \mathrm{~g} \mathrm{~L}^{-1} \mathrm{~h}^{-1}$ was comparable to that obtained under sterile conditions. Therefore, fermentation of LA using the thermophilic strain QU 50 under non-sterile conditions was possible and was selected for further experimental studies.

\section{Efficient open repeated batch fermentation with simulated energy cane hydrolysate}

In an attempt to enhance LA productivity under non-sterile conditions, 3 runs in the open repeated batch fermentation was performed with G5C40X20 by free cells under optimised conditions (Fig. 3A and Table 3). During the fermentations, DCW increased to a maximum $5.81 \mathrm{~g} \mathrm{~L}^{-1}$ in the second run from $4.26 \mathrm{~g}$ $\mathrm{L}^{-1}$ obtained in the first run, while cell growth did not occur in the third run. In all the runs, the mixed sugars were also consumed simultaneously without CCR. The second run increased the LA productivity from $3.58 \mathrm{~g} \mathrm{~L}^{-1} \mathrm{~h}^{-1}$ to $4.79 \mathrm{~g} \mathrm{~L}^{-1}$ $\mathrm{h}^{-1}$, but slightly decreased the LA concentration and cellobiose consumption from $64.4 \mathrm{~g} \mathrm{~L}^{-1}$ and $32.7 \mathrm{~g} \mathrm{~L}^{-1}$ to $57.4 \mathrm{~g} \mathrm{~L}^{-1}$ and $22.2 \mathrm{~g} \mathrm{~L}^{-1}$, respectively, as compared to the first run. The efficiency of LA fermentation in the third run was, however, drastically reduced, yielding lower values of LA productivity $\left(2.39 \mathrm{~g} \mathrm{~L}^{-1}\right.$ $\mathrm{h}^{-1}$ ), LA concentration (21.5 $\left.\mathrm{g} \mathrm{L}^{-1}\right)$, xylose consumption (13.2 $\mathrm{g}$ $\left.\mathrm{L}^{-1}\right)$, cellobiose consumption $\left(7.5 \mathrm{~g} \mathrm{~L}^{-1}\right)$, and residual sugars (44.7 $\left.\mathrm{g} \mathrm{L}^{-1}\right)$, regardless of similar DCW $\left(5.81 \mathrm{~g} \mathrm{~L}^{-1}\right)$. It was suggested that the less viability of free bacterial cells would result in low LA production during open repeated batch fermentation.

To maintain the stable activity of the strain, open repeated batch fermentation was conducted with immobilised cells with G5C40X20 supplemented with $0.5 \% \mathrm{CaCO}_{3}$ for the stabilisation of the beads (Fig. 3B and Table 3). All the beads used in the previous runs were reused for the subsequent runs. Sugar mixtures were consumed simultaneously without CCR in all the runs. After a $20 \mathrm{~h}$ culture, the maximum DCW obtained in the first run was $3.53 \mathrm{~g} \mathrm{~L}^{-1}$, which gradually increased to $3.70 \mathrm{~g} \mathrm{~L}^{-1}$ and $4.53 \mathrm{~g} \mathrm{~L}^{-1}$ in the second and third runs respectively, contributing to higher LA productivity (3.78 and $3.82 \mathrm{~g} \mathrm{~L}^{-1} \mathrm{~h}^{-1}$ ) in the following runs respectively, than that obtained in the $1^{\text {st }}$ run $\left(3.22 \mathrm{~g} \mathrm{~L}^{-1} \mathrm{~h}^{-1}\right)$. In addition, using immobilised cells, LA was produced at concentrations of 60.5-64.3 $\mathrm{g} \mathrm{L}^{-1}$ and yields of

Table 3 Kinetic parameters of lactic acid fermentation using simulated energy cane hydrolysate by E. faecium QU 50 in open repeated batch fermentation

\begin{tabular}{|c|c|c|c|c|c|c|c|c|c|c|}
\hline $\begin{array}{l}\text { Mixed } \\
\text { sugars }^{a}\end{array}$ & Cells & $\begin{array}{l}\text { Run } \\
\text { number }\end{array}$ & $\begin{array}{l}\text { Max. DCW } \\
\left(\mathrm{g} \mathrm{L}^{-1}\right)\end{array}$ & $\begin{array}{l}C_{\mathrm{Glc}}^{b} \\
\left(\mathrm{~g} \mathrm{~L}^{-1}\right)\end{array}$ & $\begin{array}{l}C_{\mathrm{Cel}}^{c} \\
\left(\mathrm{~g} \mathrm{~L}^{-1}\right)\end{array}$ & $\begin{array}{l}C_{\mathrm{Xyl}}^{d} \\
\left(\mathrm{~g} \mathrm{~L}^{-1}\right)\end{array}$ & $\begin{array}{l}\text { Max. LA } \\
\left(\mathrm{g} \mathrm{L}^{-1}\right)\end{array}$ & $\begin{array}{l}\text { Time } \\
\text { (h) }\end{array}$ & $\begin{array}{l}Y_{\mathrm{LA}}^{e} \\
\left(\mathrm{~g} \mathrm{~g}^{-1}\right)\end{array}$ & $\begin{array}{l}P_{\mathrm{LA}}^{f} \\
\left(\mathrm{~g} \mathrm{~L}^{-1} \mathrm{~h}^{-1}\right)\end{array}$ \\
\hline \multirow[t]{2}{*}{ G5C40X20 } & Free & 1 & $4.26(18 \mathrm{~h})$ & 4.00 & 32.7 & 19.9 & 64.4 & 18 & 1.14 & 3.58 \\
\hline & & 3 & $5.81(39 \mathrm{~h})$ & 5.00 & 7.5 & 13.2 & 21.5 & 9 & 0.833 & 2.39 \\
\hline \multirow[t]{2}{*}{ G5C40X20 } & Immobilisation & 1 & $3.53(20 \mathrm{~h})$ & 4.70 & 39.1 & 19.6 & 64.3 & 20 & 1.01 & 3.22 \\
\hline & & 2 & $3.70(36 \mathrm{~h})$ & 4.80 & 35.1 & 19.2 & 60.5 & 16 & 1.02 & 3.78 \\
\hline
\end{tabular}

${ }^{a}$ G5C40X20, glucose $5 \mathrm{~g} \mathrm{~L}^{-1}$, cellobiose $40 \mathrm{~g} \mathrm{~L}^{-1}$ and xylose $20 \mathrm{~g} \mathrm{~L}^{-1} \cdot{ }^{b}$ Glucose consumption. ${ }^{c}$ Cellobiose consumption. ${ }^{d}$ Xylose consumption.

${ }^{e}$ Yield of LA. ${ }^{f}$ Apparent productivity of LA. 


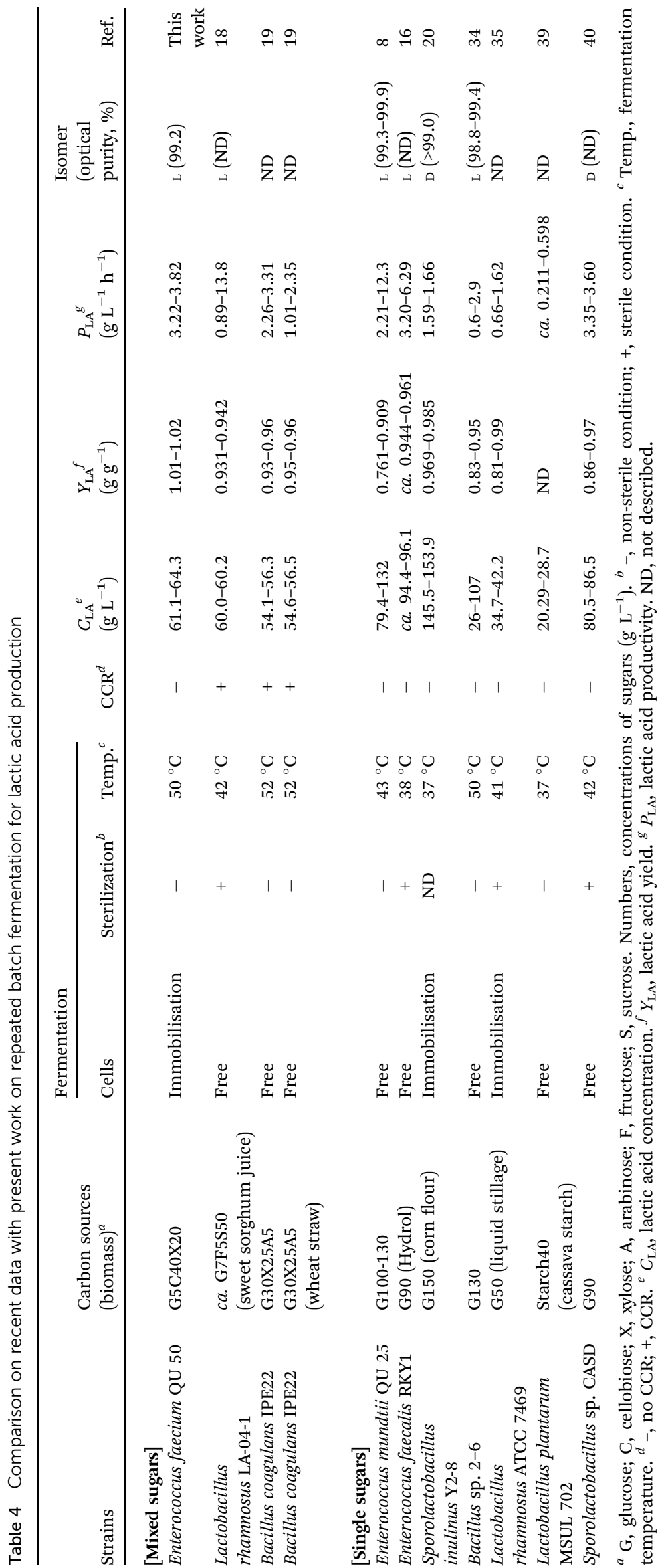


1.01-1.02 $\mathrm{g} \mathrm{g}^{-1}$ without any by-product formations. Therefore, immobilised cells of strain QU 50 resulted in a more stable LA production from mixed sugars in an open repeated batch fermentation than the free cells.

\section{Discussion}

In our previous study, we reported a newly isolated thermophilic LAB strain, QU 50, which under the optimal fermentation conditions of temperature $\left(50{ }^{\circ} \mathrm{C}\right)$ and $\mathrm{pH}(6.5)$, could use xylose as a sole substrate for the fermentation of homo-L-LA even at low concentration. ${ }^{1}$ This study aimed at establishing a homo-LA fermentation process using sugar mixtures derived from lignocellulosic substrates (glucose, cellobiose, and xylose) by strain QU 50 without CCR and by-product formation.

Our results indicated that usage of cellobiose instead of glucose could avoid CCR of xylose consumption from hexose/ pentose mixtures in QU 50 (Fig. 1B), which was similar to the phenomenon observed in E. mundtii QU 25 in our previous research. ${ }^{9}$ Although there are no other reports on this avoidance of CCR of xylose consumption using cellobiose, except for our strains of QU 50 and QU 25, it may be possible that this approach is applied and feasible for the other LAB as well. On the other hand, most LAB have exhibited obvious CCR of non-favourable sugar consumption such as xylose in the presence of preferred sugar, mainly glucose, which retards the complete consumption of sugars and decrease fermentation efficiency. ${ }^{\mathbf{8 1 9 , 2 4 - 2 6}}$ In addition, it is known that the intensities of CCR exhibited by LAB have been dependent on a concentration of preferred sugar. ${ }^{26} \mathrm{~A}$ glucose concentration higher than $25 \mathrm{~g} \mathrm{~L}^{-1}$ results in maximal CCR of xylose consumption and incomplete xylose utilisation by strain QU 25, ${ }^{24}$ whereas strain QU 50 exhibited more relaxed CCR of xylose consumption at $20 \mathrm{~g} \mathrm{~L}^{-1}$ glucose (Fig. 1A) or even at $40 \mathrm{~g}$ $\mathrm{L}^{-1}$ glucose (data not shown), and achieved almost complete xylose utilisation. Although the mechanism underlying the distinct CCR behaviour of LAB in response to different thresholds of glucose concentration is unclear, strain QU 50 is advantageous as it can be used to produce L-LA from several compositions of hexose/pentose mixtures derived from different lignocellulosic biomasses. ${ }^{1}$

It is reported that actual lignocellulosic hydrolysates consist of not only glucose, cellobiose, and xylose but also other sugars (e.g. arabinose, fructose) and inhibitors (e.g. acetate, and phenolic compounds). ${ }^{27-29}$ Small amount of glucose did not affect consumptions of cellobiose and xylose by strain QU 50 (Fig. 2). In addition, actual lignocellulosic hydrolysates including cellobiose, xylose, and small amounts of glucose, arabinose, acetate, and phenolic compounds could achieve homo-LA fermentation with no CCR by strain QU 50 (unpublished data). These results suggested that strain QU 50 would be potential to convert various types of lignocellulosic hydrolysates to LA by homofermentative manner without CCR. Because of few knowledge of LA fermentation, more studies should be done to investigate the effects of the other sugars and potential inhibitors on LA production and sugar consumptions.

It has been reported that the enzyme activities related to xylose metabolism in some LAB decrease during CCR of xylose consumption in LA fermentation with hexose/pentose mixtures. ${ }^{17,30,31}$ In this study, the results of enzyme assays indicated that the higher activities of XI and XK may contribute to the high specific consumption rate of xylose and the specific production rate of LA in QU 50 grown in C20X20, when compared to those grown in G20X20. The consumption rate of xylose $\left(1.14 \mathrm{~g} \mathrm{~L}^{-1} \mathrm{~h}^{-1}\right)$ was similar to that of cellobiose $(1.74 \mathrm{~g}$ $\mathrm{L}^{-1} \mathrm{~h}^{-1}$ ) in the fermentation with C20X20, which suggested that cellobiose consumption would not repress transcriptions of the XI and XK genes. The mechanisms of CCR of xylose consumption in hexose/pentose-grown Saccharomyces cerevisiae and Bacillus subtilis have been reported in other fermentation processes. $^{23,32}$ Extracellular glucose may inhibit the transportation of xylose from outside to the inside of the cells. Glucose was not detected in the fermentation broths outside the cells when using cellobiose (Fig. 1B) and extracellular cellobiose could not compete with xylose transportation, which would avoid CCR of xylose consumption. In addition, two proteins, serine-phosphorylated HPr and CcpA, are known to repress the transcription of the genes or operons of metabolic enzymes for non-favourable sugars at high intracellular concentrations of glucose 6-phosphate and fructose 1,6-bisphosphates. ${ }^{32}$ Because cellobiose is transported to the cells and hydrolysed to glucose ${ }^{23}$ it is suggested that the amount of glucose produced from cellobiose at any point of time is less, which resulted that intracellular concentrations of glucose 6-phosphate and fructose 1,6-biphosphates would not reach the thresholds required to induce synthesis of HPr and CcpA. However, little is known of the mechanism in E. faecium species. More studies should be done to investigate the mechanisms of CCR in strain QU 50 grown in hexose/pentose sugar mixture.

Generally, the optimal fermentation temperature of most LAB is mesophilic $\left(30-45^{\circ} \mathrm{C}\right)$, which might increase the risk of contamination to decrease fermentation efficiencies. ${ }^{1,33}$ In this study, strain QU 50 consumed sugar mixtures of G5C40X20 simultaneously and efficiently without CCR, and produced LA with comparable high yields of $1.00-1.02 \mathrm{~g} \mathrm{~g}^{-1}$ in batch and repeated batch fermentation at $50{ }^{\circ} \mathrm{C}$ under non-sterile conditions (Fig. 2 and 3, Tables 1 and 3). These results indicated that the successful performance of non-sterile fermentation may be attributed to the high temperature of $50{ }^{\circ} \mathrm{C}$, which efficiently avoided contamination during fermentation., ${ }^{\mathbf{1 , 1 3}}$ Non-sterile conditions also contribute to reducing both equipment exploitation and requirements for labour and energy. ${ }^{19}$ Although there are several reports on LA production with relatively high LA yields of $\leq 0.96 \mathrm{~g} \mathrm{~g}^{-1}$ from mixed sugars by Bacillus species (non$\mathrm{LAB})^{\mathbf{1 9 , 3 4}}$ under non-sterile conditions, we achieved open fermentation by the thermophilic strain QU 50 (LAB) with the highest yield of LA (1.00-1.02 $\mathrm{g} \mathrm{g}^{-1}$ ) reported till date.

In this study, we also found that cell immobilisation could contribute to the operational stability of LA production from mixed sugars (Fig. 3 and Table 3). During the open repeated batch fermentation, the LA concentration and yield using free cells decreased from $64.4 \mathrm{~g} \mathrm{~L}^{-1}$ and $1.14 \mathrm{~g} \mathrm{~g}^{-1}$ in the first run to $21.5 \mathrm{~g} \mathrm{~L}^{-1}$ and $0.833 \mathrm{~g} \mathrm{~g}^{-1}$ in the third run, while more stable LA concentration with LA yield (60.5-64.3 $\mathrm{g} \mathrm{L}^{-1}$ and 1.01-1.02 $\mathrm{g} \mathrm{g}^{-1}$ ) was produced by immobilising strain QU 50. Studies that 
compared the stabilities of LA production in batch fermentation, ${ }^{35}$ repeated batch fermentation ${ }^{20,35,36}$ and continuous fermentation $^{37}$ reported better operational stability of LA production when cells were immobilised. To the best of our knowledge, there is no previous literature investigating the effect of free and immobilised LAB cells on the stability of LA fermentation with mixed sugars in a non-sterile condition. Therefore, this is the first report of a stable LA production leading to the highest LA yield from mixtures of xylose, cellobiose, and glucose by immobilised strain QU 50 in an open repeated batch fermentation. Further work is required to investigate the effects of combinational factors on LA production by a statistical experiment such as response surface methodology ${ }^{21,38}$ to improve the efficiency of LA fermentation with sugar mixture.

Repeated batch fermentation has several advantages including an increase in total LA concentration, enhancement of LA productivity, and decrease in fermentation time. ${ }^{19,34}$ We successfully performed efficient open repeated batch fermentation with sugar mixtures of simulated energy cane hydrolysate, and all of the sugars were consumed completely and simultaneously in all the runs by strain QU 50 without CCR (Fig. 3 and Table 3). Moreover, we achieved higher LA productivity (3.78$\left.3.82 \mathrm{~g} \mathrm{~L}^{-1} \mathrm{~h}^{-1}\right)$ and shorter fermentation time $(16 \mathrm{~h})$ in the second and third runs than in the first run $\left(3.22 \mathrm{~g} \mathrm{~L}^{-1} \mathrm{~h}^{-1}\right.$ and 20 h). This can be attributed to the high inoculations in the subsequent runs. Some data from previous works on open repeated batch fermentation for LA production are shown in Table 4..$^{8,1934,39}$ Among these studies, Zhang et al. ${ }^{19}$ reported an open repeated batch fermentation with sugar mixtures, although CCR was exhibited in the study. To the best of our knowledge, this is the first report on L-LA production by LAB in an open repeated batch culture without CCR from mixed sugars.

\section{Conclusion}

This study demonstrated that E. faecium QU 50, at a high temperature of $50{ }^{\circ} \mathrm{C}$, could lead to efficient homo-L-LA production from sugar mixtures of glucose/xylose and cellobiose/xylose without either forming any by-products or exhibiting CCR. The activities of XI and XK influenced the specific consumption rate of xylose and resulted in relaxed CCR in cells grown in glucose/ xylose and no CCR in cells grown in cellobiose/xylose. Furthermore, the use of $\mathrm{NH}_{4} \mathrm{OH}$ as a pH neutraliser improved both cell growth and LA productivity. In addition, strain QU 50 consumed simulated energy cane hydrolysate simultaneously to produce homo-L-LA with an yield of $1 \mathrm{~g} \mathrm{~g}^{-1}$ without CCR under non-sterile conditions. Finally, we first reported that immobilised strain QU 50 could produce stable L-LA with yields of $1.01-1.02 \mathrm{~g} \mathrm{~g}^{-1}$ in an open repeated batch fermentation using mixed sugars derived from lignocellulosic biomass.

\section{Abbreviations}

$\begin{array}{ll}\text { LA } & \text { Lactic acid } \\ \text { PLA } & \text { Poly-lactic acid } \\ \text { PLLA } & \text { Poly-L-LA }\end{array}$

$\begin{array}{ll}\text { LAB } & \text { Lactic acid bacteria } \\ \text { CCR } & \text { Carbon catabolite repression } \\ \text { XI } & \text { Xylose isomerase } \\ \text { XK } & \text { Xylulose kinase } \\ \text { mMRS } & \text { Modified de Man, Rogosa, and Sharpe } \\ \text { G20X20 } & 20 \mathrm{~g} \mathrm{~L}^{-1} \text { glucose and } 20 \mathrm{~g} \mathrm{~L}^{-1} \text { xylose } \\ \text { C20X20 } & 20 \mathrm{~g} \mathrm{~L}^{-1} \text { cellobiose, and } 20 \mathrm{~g} \mathrm{~L}^{-1} \text { xylose } \\ \text { G5C40X20 } & 5 \mathrm{~g} \mathrm{~L}^{-1} \text { glucose, } 40 \mathrm{~g} \mathrm{~L}^{-1} \text { cellobiose, and } \\ & 20 \mathrm{~g} \mathrm{~L}^{-1} \text { xylose } \\ \text { HPr } & \text { Phospho-carrier protein } \\ \text { CcpA } & \text { Catabolite control protein A }\end{array}$

\section{Acknowledgements}

This study has been partly supported by Kyushu University, Japan to Mohamed Ali Abdel-Rahman under the International Exchange Agreement Promotional Program between Kyushu University and Al-Azhar University, Egypt. Jiaming Tan gratefully acknowledges the support of a Chinese government scholarship offered by the China Scholarship Council (CSC) during this study.

\section{References}

1 M. A. Abdel-Rahman, Y. Tashiro, T. Zendo, K. Sakai and K. Sonomoto, FEMS Microbiol. Lett., 2015, 362, 1-7.

2 Y. Tashiro, W. Kaneko, Y. Sun, K. Shibata, K. Inokuma, T. Zendo and K. Sonomoto, Appl. Microbiol. Biotechnol., 2011, 89, 1741-1750.

3 Y. Wee, J. Kim and H. Ryu, Food Technol. Biotechnol., 2006, 44, 163-172.

4 N. Burgos, D. Tolaguera, S. Fiori and A. Jiménez, J. Polym. Environ., 2014, 22, 227-235.

5 N. Nagasawa, A. Kaneda, S. Kanazawa, T. Yagi, H. Mitomo, F. Yoshii and M. Tamada, Nucl. Instrum. Methods Phys. Res., Sect. B, 2005, 236, 611-616.

6 J. Tan, M. A. Abdel-Rahman and K. Sonomoto, in Advances in Polymer Science, Springer, Berlin Heidelberg, 2017, ch. 11, pp. 1-40.

7 D. Kim, M. Lee, Y. Hwang, W. Im, Y. Yun, C. Park and M. Kim, Biotechnol. Bioeng., 2016, 113, 101-111.

8 M. A. Abdel-Rahman, Y. Tashiro and K. Sonomoto, Biotechnol. Adv., 2013, 31, 877-902.

9 Y. Wang, M. A. Abdel-Rahman, Y. Tashiro, Y. Xiao, T. Zendo, K. Sakai and K. Sonomoto, RSC Adv., 2014, 4, 22013-22021.

10 T. Jojima, C. A. Omumasaba, M. Inui and H. Yukawa, Appl. Microbiol. Biotechnol., 2010, 85, 471-480.

$11 \mathrm{~J}$. Kim, D. E. Block and D. A. Mills, Appl. Microbiol. Biotechnol., 2010, 88, 1077-1085.

12 N. Nakamura, R. Yamada, S. Katahira, T. Tanaka, H. Fukuda and A. Kondo, Enzyme Microb. Technol., 2008, 43, 233-236.

13 M. A. Abdel-Rahman, Y. Tashiro, T. Zendo and K. Sonomoto, RSC Adv., 2013, 3, 8437-8445.

14 S. Ding and T. Tan, Process Biochem., 2006, 41, 1451-1454.

15 M. A. Abdel-Rahman, Y. Tashiro, T. Zendo, K. Sakai and K. Sonomoto, RSC Adv., 2016, 6, 17659-17668. 
16 L. V. Reddy, Y. Kim, J. Yun, H. Ryu and Y. Wee, Bioresour. Technol., 2016, 209, 187-194.

17 Y. Wee and H. Ryu, Bioresour. Technol., 2009, 100, 42624270.

18 Y. Wang, H. Meng, D. Cai, B. Wang, P. Qin, Z. Wang and T. Tan, Bioresour. Technol., 2016, 211, 291-297.

19 Y. Zhang, X. Chen, B. Qi, J. Luo, F. Shen, Y. Su, R. Khan and Y. Wan, Bioresour. Technol., 2014, 163, 160-166.

20 T. Zhao, D. Liu, H. Ren, X. Shi, N. Zhao, Y. Chen and H. Ying, J. Microbiol. Biotechnol., 2014, 24, 1664-1672.

21 R. P. John, R. Sukumaran, K. M. Nampoothiri and A. Pandey, Biochem. Eng. J., 2007, 36, 262-267.

22 G. Xu, J. Chu, Y. Wang, Y. Zhuang, S. Zhang and H. Peng, Process Biochem., 2006, 41, 2458-2463.

23 S. Ha, J. M. Galazka, S. R. Kim, J. Choi, X. Yang, J. Seo, N. L. Glass, J. H. D. Cate and Y. Jin, Proc. Natl. Acad. Sci. U. S. A., 2011, 108, 504-509.

24 M. A. Abdel-Rahman, Y. Xiao, Y. Tashiro, Y. Wang, T. Zendo, K. Sakai and K. Sonomoto, J. Biosci. Bioeng., 2015, 119, 153158.

25 M. Ilmén, K. Koivuranta, L. Ruohonen, P. Suominen and M. Penttilä, Appl. Environ. Microbiol., 2007, 73, 117-123.

26 S. Hama, S. Mizuno, M. Kihara, T. Tanaka, C. Ogino, H. Noda and A. Kondo, Bioresour. Technol., 2015, 187, 167-172.

27 A. Berlin, V. Maximenko, N. Gilkes and J. Saddler, Biotechnol. Bioeng., 2007, 97, 287-296.
28 Y. Zhang, X. Chen, J. Luo, B. Qi and Y. Wan, Bioresour. Technol., 2014, 158, 396-399.

29 A. Martinez, M. E. Rodriguez, M. L. Wells, S. W. York, J. F. Preston and L. O. Ingram, Biotechnol. Prog., 2001, 17, 287-293.

30 J. Kim, S. P. Shoemaker and D. A. Mills, Microbiology, 2009, 155, 1351-1359.

31 S. Yoshida, K. Okano, T. Tanaka, C. Ogino and A. Kondo, Appl. Microbiol. Biotechnol., 2011, 92, 67-76.

32 B. Görke and J. Stülke, Nat. Rev. Microbiol., 2008, 6, 613-624.

33 M. A. Abdel-Rahman and K. Sonomoto, J. Biotechnol., 2016, 236, 176-192.

34 B. Zhao, L. Wang, C. Ma, C. Yang, P. Xu and Y. Ma, Bioresour. Technol., 2010, 101, 6494-6498.

35 A. P. Djukić-Vuković, L. V. Mojović, B. M. Jokić, S. B. Nikolić and J. D. Pejin, Bioresour. Technol., 2013, 135, 454-458.

36 H. Yen and Y. Lee, Appl. Biochem. Biotechnol., 2010, 162, 607615.

37 S. S. Kanwar, B. S. Chadha, H. K. Tewari and V. K. Sharma, World J. Microbiol. Biotechnol., 1995, 11, 687-688.

38 L. Yu, T. Lei, X. Ren, X. Pei and Y. Feng, Biochem. Eng. J., 2008, 39, 496-502.

39 S. Tosungnoen, K. Chookietwattana and S. Dararat, APCBEE Proc., 2014, 8, 204-209.

40 B. Zhao, L. Wang, F. Li, D. Hua, C. Ma, Y. Ma and P. Xu, Bioresour. Technol., 2010, 101, 6499-6505. 